\title{
REVIEW
}

\section{Phosphodiesterases in endocrine physiology and disease}

\author{
Delphine Vezzosi ${ }^{1,2,3}$ and Jérôme Bertherat ${ }^{1,2,4}$ \\ ${ }^{1}$ Inserm U1016, CNRS UMR 8104, Institut Cochin, 75014 Paris, France, ${ }^{2}$ Faculté de Médecine Paris 5, Université Paris Descartes, 75005 Paris, \\ France, ${ }^{3}$ Department of Endocrinology, Hôpital Larrey, 31480 Toulouse, France and ${ }^{4}$ Department of Endocrinology, Reference Center for Rare Adrenal \\ Diseases, Assistance Publique Hôpitaux de Paris, Hôpital Cochin, APHP, 75014 Paris, France \\ (Correspondence should be addressed to D Vezzosi; Email: delphine.vezzosi@gmail.com)
}

\begin{abstract}
The cAMP-protein kinase A pathway plays a central role in the development and physiology of endocrine tissues. cAMP mediates the intracellular effects of numerous peptide hormones. Various cellular and molecular alterations of the cAMP-signaling pathway have been observed in endocrine diseases.

Phosphodiesterases (PDEs) are key regulatory enzymes of intracellular cAMP levels. Indeed, PDEs are the only known mechanism for inactivation of cAMP by catalysis to $5^{\prime}$-AMP. It has been suggested that disruption of PDEs could also have a role in the pathogenesis of many endocrine diseases. This review summarizes the most recent advances concerning the role of the PDEs in the physiopathology of endocrine diseases. The potential significance of this knowledge can be easily envisaged by the development of drugs targeting specific PDEs.
\end{abstract}

European Journal of Endocrinology 165 177-188

\section{Introduction}

The cAMP pathway plays an important role in the development and function of endocrine tissues. It is also altered in various endocrine disorders. Indeed, numerous genetic alterations of the cAMP-signaling pathway have been observed (1). First, abnormalities of the hormone receptor of a given endocrine pathway have been reported, for example, activating mutations of the gene encoding for the TSH receptor (TSHR) in thyroid toxic adenomas (2), for the LH receptor in Leydig cell tumors (3), for the calcium sensing receptor in familial hypocalcaemia (4), and aberrant expression of G-protein-coupled receptors in bilateral macronodular adrenal hyperplasia (5-7). Secondly, somatic activating mutations of the stimulatory subunit $\alpha$ of the Gs protein have been found in McCune-Albright syndrome or in sporadic pituitary GH adenomas $(8,9)$. Finally, germ line inactivating mutations of the protein kinase A regulatory subunit type 1 (PRKAR1A) have been demonstrated in primary pigmented nodular adrenocortical diseases (PPNAD) and Carney complex (CNC) (10-12).

Phosphodiesterases (PDEs) have a key regulatory role in the cAMP pathway, as they are the only known mechanism for inactivating CAMP by its catalysis to 5'-AMP (Fig. 1). During the last several years, various attempts have been made to identify diseases associated with disruption of PDEs. Gene knockout, gene inactivation, and genetic association studies have implicated
PDEs in numerous diseases such as asthma (13), depression (14), schizophrenia (15), and stroke (16). Moreover, in daily clinical practice, PDE inhibitors are able to effectively and safely treat diseases such as erectile dysfunction (17), heart failure (18), severe forms of Raynaud's phenomenon (19), pulmonary arterial hypertension (20), and chronic obstructive pulmonary disease or asthma $(21,22)$.

In this review, a brief overview of the PDE family will be presented, followed by a description of their role in endocrine physiology. Finally, the known and potential roles of PDEs in endocrine diseases will be discussed.

\section{The PDE superfamily}

Adenylyl and guanylyl cyclases are the effector enzymes accounting for cyclic nucleotide production by converting ATP to cAMP or GTP to cGMP respectively. By contrast, PDEs cause the cyclic nucleotide degradation by hydrolyzing cAMP into $5^{\prime}$-AMP or, depending on the type of PDE, cGMP into $5^{\prime}$-GMP. Thus, PDEs play a critical role in the intracellular cAMP and cGMP homeostasis. Moreover, in combination with A-kinase anchoring proteins (AKAPs), PDEs contribute to compartmentalizing the cyclic nucleotides. It has been shown that cAMP does not have a uniform intracellular distribution but accumulates at specific sites within a cell. AKAPs, PDEs, and protein kinase A (PKA) form 


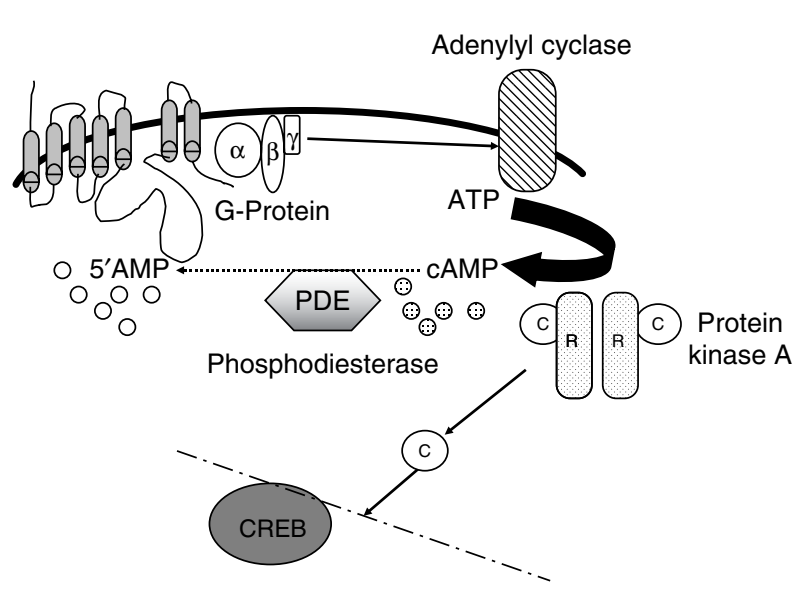

Figure 1 Phosphodiesterases in the CAMP pathway. The cAMP pathway mediates key cellular processes. When the G-proteincoupled receptor is activated by an extracellular ligand, a conformational change occurs. The Gs $\alpha$ subunit is released from the complex and binds to adenylyl cyclase, which then catalyzes the conversion of ATP into cAMP. Elevation in intra-cellular cAMP levels leads to dissociation of the catalytic subunit from the regulatory subunit of the protein kinase $A$. The activated protein kinase $A$ can then phosphorylate a series of targets that regulate downstream effector enzymes, ion channels, and activates the transcription of specific genes mediating cell growth and differentiation. Phosphodiesterases are key regulators of the CAMP pathway, as they are able to hydrolyze the cAMP to inactive $5^{\prime}$-AMP leading to inactivation CAMP pathway. Abbreviations used: CREB, cAMP response element-binding protein; CAMP, cyclic adenosine monophosphate; $5^{\prime}$-AMP, $5^{\prime}$-adenosine monophosphate.

complexes that act to create these simultaneous, multiple cAMP gradients. A cell without theses complexes and PDEs would be swamped with cAMP after activation of adenylyl cyclase. Thus, PDEs have a major role in ensuring the proper intensity and spatiotemporal distribution of cyclic nucleotides $(14,23)$.

Human PDEs comprise a complex superfamily of enzymes derived from 21 genes separated into 11 PDE gene families (PDE 1-11; Fig. 2). Transcription from different initiation sites in these genes and differential splicing of their mRNAs results in the generation of about 100 isoforms of PDE proteins found in all cells and in almost all subcellular compartments. These isoforms can have different substrate selectivity (cAMP versus cGMP), kinetics, allosteric regulation, tissue distribution, and susceptibility to pharmacological inhibition. Although PDEs are structurally, biochemically, and pharmacologically different, they share some common structural features. They contain a conserved catalytic domain with $\sim 300$ amino acids located near the C-terminal regions and a variable regulatory domain located in the $\mathrm{N}$-terminal regions. In mammals, three of the 11 PDE families selectively hydrolyze cAMP (PDEs 4, 7, and 8), three families are selective for cGMP (PDEs 5, 6, and 9), and five families present a dual specificity for both cyclic nucleotides but with variable efficiency (PDEs 1, 2, 3, 10, and 11).
Nowadays, it has been demonstrated that six PDE families could have a role in endocrine physiology and endocrine diseases: PDE1, PDE2 (PDE2A), PDE3 (PDE3A), PDE4 (PDE4B and PDE4D), PDE8 (PDE 8A and PDE $8 B$ ), and PDE11 (PDE11A). The major properties and localization of PDEs are summarized in Table 1. However, it is important to underline that understanding PDE functions can be difficult due to the lack of selective pharmacological inhibitors and to the fact that the catalytic properties of many PDEs overlap, so that assignation of a specific role to a particular PDE family or to variants within a family is typically challenging.

Moreover, expression pattern of PDEs isoforms frequently varies with the developmental, proliferative status and with the hormonal stimuli of the cell. In addition, these PDE isoforms are subjected to different regulations or are targeted to different subcellular compartments that account at least in part for creation of microdomains that spatially restrict cyclic nucleotides diffusion. This phenomenon could take part in a tissue specificity of the consequences of PDE mutations.

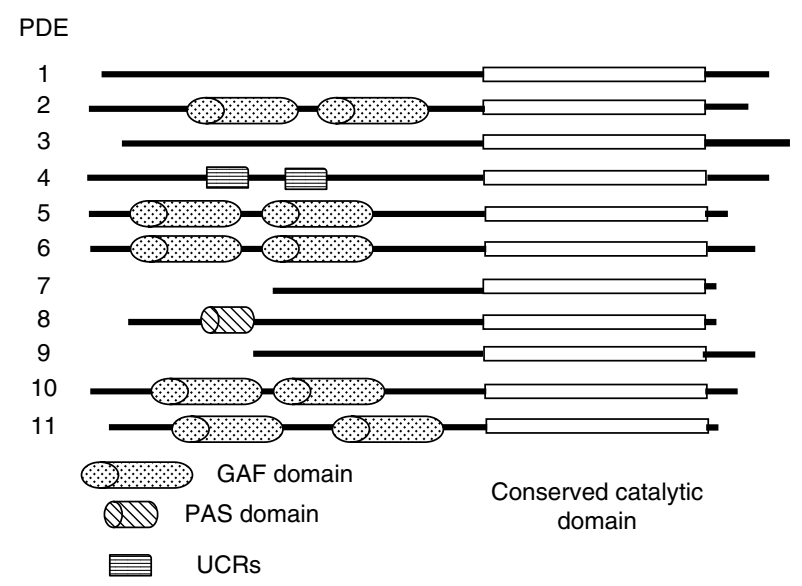

Figure 2 Schematic representation of the human phosphodiesterases. Adapted from $(76,77)$. Phosphodiesterases are isoenzymes encoded by at least 21 different genes and organized into 11 families. Transcription from different initiation sites in these genes and differential splicing of their mRNAs results in the generation of about 100 isoforms of PDE proteins. GAF domains are one of the largest families of small molecule binding units. They regulate the catalytic activity of phosphodiesterases by allosteric binding of cyclic nucleotides. The GAF acronym arises from the names of the first three different classes of proteins identified to contain them: cGMP-specific and cGMP-regulated cyclic nucleotide phosphodiesterase, adenylyl cyclase, and the bacterial transcription factor FhIA. PAS domains, named for Per, ARNT, and Sim, are a ubiquitous class of transduction domains. There is a considerable overlap between the function of GAF and PAS domains. Of the 11 PDE families, PDEs 2, 5, 6, 10, and 11 contain GAF domains in their $\mathrm{N}$-terminal regulatory regions and one, PDE8, contains a PAS domain. The PDE4 family contains a unique structural feature, two domains in the $\mathrm{N}$-terminal region called upstream conserved region 1 and 2 (UCR1 and UCR2). These domains have been shown to form a module necessary for the activation of PDE4 upon phosphorylation by protein kinase $\mathrm{A}$. 
Table 1 Major properties and localization of the phosphodiesterases.

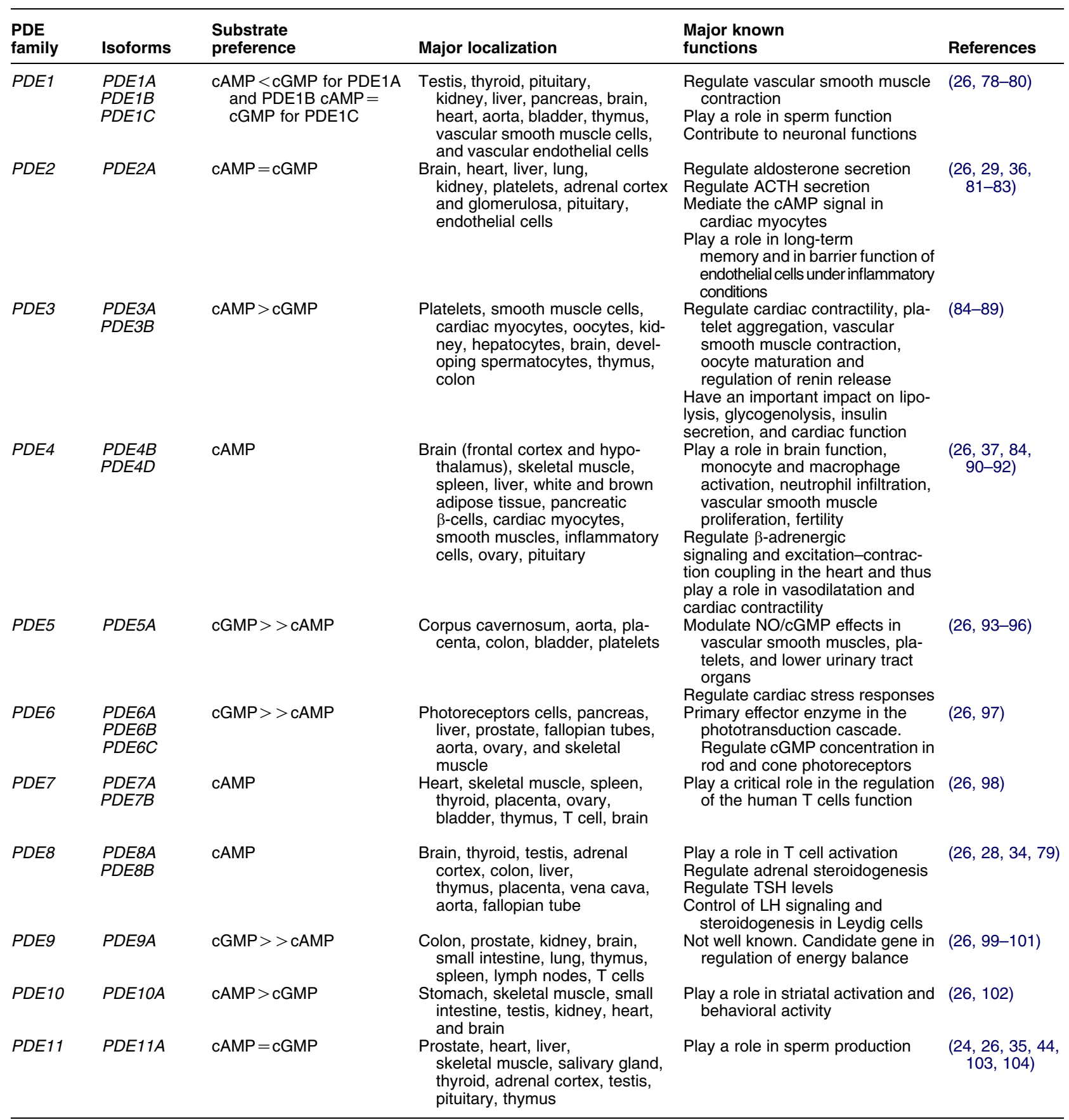

PDE, Phosphodiesterases

\section{PDEs in endocrine physiology}

\section{Adrenals}

PDE2A, PDE8A, PDE8B, and PDE11A are the major PDEs that are expressed in the adrenal cortex (24-26). Recently, it has been demonstrated that PDE2A, PDE8B, and PDE11A have a role in the adrenal physiology.
PDE2A PDE $2 A$ is the predominant PDE in the adrenal cortex and may be implicated in adrenal physiology $(25$, $27,28)$. To date, the regulation of intracellular cAMP accumulation after ACTH stimulation is not fully elucidated. PDE2A may be implicated in the regulation of the ACTH-induced increase in intracellular cAMP. In rat and human cell models, three sequential phases of the effect of ACTH leading to cAMP stimulation have 
been described. First, a rapid and sustained activation of adenylyl cyclase was shown followed with a biphasic effect of ACTH on PDE2 activity with an initial and rapid inhibition of $P D E 2$ activity followed with a delayed activation of PDE2A (29). Thus, PDE2A seems to be strongly involved in the regulation of cAMP levels as its activity controls the production of cAMP induced by ACTH.

PDE8B Recently, it was demonstrated that PDE8B is a major regulator of adrenal steroidogenesis by both acute and chronic mechanisms (28). Indeed, PDE8B knockout mouse have elevated levels of corticosterone due to adrenal hypersensitivity to ACTH. In cell culture models, pharmacological inhibition of PDE8 has the same effects. This suggests that in normal adrenal cortex, PDE8B acts as a negative regulator of adrenal steroidogenesis.

PDE11A4 The role of PDE11A4 in adrenal physiology has been poorly investigated. Mice deficient in PDE11A4 have been generated but no effects on the adrenal have been reported (30). Even if selective PDE11 inhibitors have not yet been discovered, inhibitors that can partially inhibit PDE11 have been used in murine models and in humans. Tadalafil, a PDE5 inhibitor that can partially inhibit PDE11, is widely used without reports of adrenal dysfunction. Tadalafil was used to study glucocorticoid secretion after a maximal exerciserelated stress in healthy humans (31). Conversely, it was shown that tadalafil administration is able, compared to placebo, to amplify mean salivary cortisol. The sites of action and the mechanisms involved in the observed effect of tadalafil on the hypothalamus-pituitaryadrenal axis response to physical stress are not known. However, these results suggest that PDE5 and/or PDE11A4 could have a role in the regulation of the hypothalamus-pituitary-adrenal axis.

\section{Thyroid}

PDE1A, PDE7A, and PDE8B are the PDEs most highly expressed in the thyroid $(25,26)$.

TSH regulates thyroid function through stimulation of the cAMP pathway. Its serum level is a sensitive indicator of thyroid function even within the normal range. It has been suggested that up to $65 \%$ of baseline TSH levels are genetically determined and could vary within the limit of the normal range in healthy people $(32,33)$.

Recently, a genome-wide association study was performed to identify genes associated with TSH levels in normal subjects (34). The strongest association was shown at the PDE8B locus. Indeed, an association between a single nucleotide polymorphism rs4704397 in the PDE8B gene and circulating TSH levels was observed. This suggests that PDE $8 B$ is one of the major genetic determinants of TSH levels. Each additional copy of the minor PDE 8B A allele was associated with a TSH increase of $0.13 \mathrm{mUI} / \mathrm{l}$ (thyroxine $\left(\mathrm{T}_{4}\right)$ and triiodothyronine $\left(\mathrm{T}_{3}\right)$ levels were not assessed in this study). This finding in the Sardinian population was confirmed by a meta-analysis that included multiple populations (34). The proposed mechanism by which PDE 8B may influence TSH levels is through control of cAMP signaling. PDE $8 B$ acts in the thyroid to catalyze the hydrolysis and inactivation of cAMP after TSH signaling. Thus, PDE8B polymorphisms may reduce cAMP in the thyroid, leading to a decreased thyroid stimulatory response to TSH and hence lower subsequent thyroid hormone production. This is likely to result via feedback in a higher TSH levels required to maintain $\mathrm{T}_{4}$ and $\mathrm{T}_{3}$ in the normal range. However, the consequence of this PDE $8 B$ polymorphism has not yet been shown in vitro.

Thus, it is possible that PDE $8 B$ genetic variants might be involved in regulation of TSH levels.

\section{Pituitary}

PDE1, PDE2, PDE4, and PDE11A are the PDEs most highly expressed in the pituitary (35-40).

The physiological role of these PDEs in human pituitary has not been extensively investigated. Nonetheless, few studies conducted in rodents' adenohypophysis demonstrated that PDEs have a role in the release of prolactin and ACTH.

First, it was shown that the addition of 3-isobutyl1methylxanthine (IBMX), a common inhibitor of PDE subtypes, increased cyclic nucleotides in primary culture of rats anterior pituitary cells (41). Moreover, application of IBMX caused a dose-dependent increase in basal prolactin release. In addition, PDE4 inhibitors are known to activate the hypothalamic-pituitaryadrenocortical system at the pituitary level, implicating PDE4 in the control of corticotroph cell function (42, 43). Recently, it was demonstrated that PDE1 and PDE4 are key cAMP metabolizing enzymes in rat corticotrophs cells (38). In the normal human pituitary gland and similarly to that reported in rodent pituitary, PDE activity was almost completely inhibited by IBMX treatment with major and similar contributions of the PDE1 and the PDE4 (37).

\section{Gonads}

Testis PDEs 1A, 1C, 3B, 5A, 8A, 10A, 11A are those most highly expressed in the testis $(26,44,45)$.

The role of two of these PDEs has been investigated and demonstrated in the testis: PDE11A in spermatozoa physiology and PDE8A in the regulation of hormone production.

PDE11A. PDE11A plays a role in spermatozoa physiology. However, data are conflicting. PDE11A-deficient 
mice present with alterations of spermatogenesis and sperm function. A significant reduction in sperm progression rate, sperm concentration, and percentage of alive ejaculated sperm compared with wild-type mice were shown in Pde11 $1 a^{-/-}$mice (30). However, despite these alterations, the fertility of PDE11-null mice and the viability, histological features, and anatomical abnormalities of offspring were comparable to that of wild-type mice.

Another way to demonstrate the role of PDE11A in spermatozoa physiology is to use PDE11A inhibitors. Tadalafil, a PDE5 inhibitor, has been tested, as it is the most effective available PDE11A inhibitor. There are conflicting reports about the inhibition of PDE11A using this medication. In a clinical trial, daily intake of tadalafil at doses of 10 and $20 \mathrm{mg}$ for 6 months produced no change in spermatogenesis or reproductive hormones in men (46). Another study demonstrated that tadalafil causes a statistically significant decrease in sperm motility (47). In mice, it was shown that chronic overexposure to tadalafil causes testicular tissue alterations with decreased testis weight, degeneration, and atrophy of the seminiferous epithelium and decrease in sperm production.

As tadalafil inhibits PDE11 activity with a 40-fold weaker potency than for PDE 5 activity, these effects should be carefully assessed before concluding that they are simply attributable to PDE11A inhibition in the testis (48).

These findings could be consistent with the involvement of the cAMP signaling pathway, and particularly PDE11A, in testis functions. However, studies with a potent and selective PDE11A inhibitor and more extensive clinical studies should be pursued to investigate the effects of PDE11A inhibition in testicular and sperm function.

PDE8A. Leydig cells are interstitial cells located adjacent to the seminiferous tubules in the testis and produce testosterone under the control of LH. cAMP is the major intracellular messenger for $\mathrm{LH}$ action on steroidogenesis, as stimulation of testosterone production by $\mathrm{LH}$ in Leydig cells is known to be mediated by an increase in the levels of cAMP (49).

PDE8A plays a key role in the control of LH signaling and steroidogenesis in Leydig cells. Using PDE8Adeficient mice, it was shown that LH-induced testosterone basal release was increased compared with controls (50). Leydig cells from deficient mice are sensitized to the effects of LH on testosterone synthesis. Thus, pharmacological manipulation of PDE $8 A$ could be used to modulate testosterone synthesis and represents a potential pharmacological target for modulation of testosterone synthesis.

Ovary The PDEs, PDE $3 A$ and $P D E 4 D$ are highly expressed in human ovary $(26,51,52)$.

PDE 3A. PDE 3 is the predominant functional PDE family expressed in human oocytes (52). In addition, it has been demonstrated that inhibition of PDE3A blocks oocyte maturation in vitro and in vivo (53). Similarly, PDE3A-deficient mice are viable and ovulate a normal number of oocytes but are completely infertile as their oocytes contain higher levels of cAMP and fail to undergo spontaneous maturation (54).

PDE4D. PDE4D also plays a critical role in the ovarian follicle. It was shown in follicle culture that PDE4 inhibitors cause oocyte maturation in the absence of gonadotropin stimulation (55). In addition, s.c. injection of PDE4 inhibitors alone or in combination with low doses of human chorionic gonadotropin could induce ovulation in rats (56). Moreover, mice deficient in Pde $4 d$ exhibit impaired ovulation with reduced female fertility (57). This decrease in fertility is caused by impaired follicular function and development. Although inactivation of $P d e 4 d$ does not cause a complete arrest of follicular development, the reduced viability of the oocytes in $P d e 4 d^{-1-}$ mice resulted in a consequent reduced number of ovulated oocytes. Furthermore, a diminished sensitivity of the granulosa cells to gonadotropins at the level of receptor-G-protein coupling might also take part in the decreased fertility of these mice. Gonadotropin responses at the level of cAMP accumulation in granulosa cells, estrogen production, and ovulation rate were decreased, suggesting that granulosa cell differentiation is disrupted after the inactivation of $P d e 4 d$.

\section{PDEs and endocrine diseases}

Table 2 summarizes the major implications of PDEs in endocrine diseases.

\section{Adrenals}

Primary PPNAD is a bilateral form of micronodular adrenal hyperplasia causing ACTH-independent Cushing syndrome. Most patients with PPNAD suffer from $\mathrm{CNC}$. This is an autosomal dominant multiple neoplasia syndrome responsible for skin pigmented lesions, cardiac myxomas, and other endocrine and nonendocrine tumors. The CNC gene 1 encodes the PRKAR1A (58). However, over the last several years, it has become apparent that PPNAD, when isolated without other clinical signs of $\mathrm{CNC}$, was less frequently explained by PRKAR 1A mutations. Germ-line mutations in two PDEs, PDE11A and PDE8B, have been identified in such patients. Figure 3 summarizes the implications of these PDEs in adrenal Cushing syndrome.

PDE11A A genome-wide scan associated with the study of allelic losses in the adrenal tumors of PPNAD patients using DNA chips have identified a region in 2q31-2q35 that encompasses the PDE11A gene (24). Further sequencing of the PDE11A gene in 16 patients 
Table 2 Major implications of the phosphodiesterases in endocrine disease.

\begin{tabular}{|c|c|c|c|}
\hline PDE family & Organs & Implication & References \\
\hline$P D E 2 A$ & Pituitary & $\begin{array}{l}\text { Could have a role in the pathogenesis of GH-secreting adenomas because of } \\
\text { protein interaction between AIP and PDE2A }\end{array}$ & $(72)$ \\
\hline \multirow[t]{2}{*}{ PDE4 } & Thyroid & $\begin{array}{l}\text { Could have a role in the autonomous thyroid adenomas bearing a TSHR or Gs } \alpha \\
\text { mutation }\end{array}$ & $(65)$ \\
\hline & Pituitary & $\begin{array}{l}\text { Could have a role in the pathogenesis of GH-secreting adenomas because of } \\
\text { protein interaction between AIP and PDE4A5 }\end{array}$ & $(37,67,69-71)$ \\
\hline \multirow[t]{3}{*}{ PDE8B } & Adrenals & Predisposition gene to PPNAD (inactivating point mutations) & $(62,63)$ \\
\hline & Thyroid & $\begin{array}{l}\text { Association of the PDE8B rs } 4704397 \mathrm{snp} \text { and circulating TSH levels. This } \\
\text { association may be responsible for the increased TSH in patients with no } \\
\text { evidence of thyroid autoimmunity and for subclinical hypothyroidism during } \\
\text { pregnancy }\end{array}$ & $(34,64)$ \\
\hline & Pituitary & Altered expression in $\mathrm{GH}$-secreting adenomas & (37) \\
\hline \multirow[t]{2}{*}{ PDE11A } & Adrenals & $\begin{array}{l}\text { Predisposition gene to PPNAD (inactivating point mutations, leading mainly to } \\
\text { premature stop codon). Missense variants of PDE11A were found with } \\
\text { increased frequency among patients with macronodular adrenocortical } \\
\text { hyperplasia, adrenocortical adenomas, and adrenal cancer compared with } \\
\text { control patients. PDE11A is a modifier of the phenotype in patients with CNC } \\
\text { due to PRKAR1A mutations }\end{array}$ & $(24,59-61)$ \\
\hline & Testis & $\begin{array}{l}\text { Association between non-synonymous substitutions of } P D E 11 A \text { and familial } \\
\text { testicular germ cell tumors }\end{array}$ & $(74)$ \\
\hline
\end{tabular}

PDE, Phosphodiesterases

with PPNAD but with no PRKAR1A mutation has uncovered five germ-line sequence variations, two producing a frameshift mutation disrupting the PDE11A4 adrenal-specific isoform protein, two missense substitutions, and one substitution that led to a premature stop codon. A decreased expression of PDE11A4 within the adrenal tumors of these patients was observed, together with increased cAMP and cGMP levels $(24,59)$. Subsequently, missense variants of PDE11A that are rare in the general population were found with increased frequency among patients with macronodular adrenocortical hyperplasia, adrenocortical adenomas, and adrenal cancer (60). This association of PDE11A4 variants and adrenocortical tumors suggests a role in the susceptibility to develop these tumors. Moreover, consistent with the hypothesis that PDE11A may play a role as a tumor suppressor gene, it has been reported that adrenal tumors expressing PDE11A variants present a loss of the wild-type allele, thus resulting in a significant reduction of enzyme levels in the affected tissue.

In addition, in patients with $\mathrm{CNC}$ and PRKAR1A inactivating mutations, an association of these PDE11A variants with the development of PPNAD and testicular tumors has been demonstrated. This suggests that PDE11A could be a modifier gene of the phenotype in patients with CNC due to PRKAR1A mutation (61). In vitro studies have shown that the simultaneous inactivation of PRKAR1A and PDE11A by siRNA leads to a stimulation of the PKA-dependent transcription (61). These observations are compatible with the hypothesis of a synergistic effect of PRKAR $1 A$ mutations and PDE11A4 variants in the tissues expressing PDE11A4 and in which tumorigenesis is sensitive to the dysregulation of the cAMP/PKA pathway.
PDE8B During the genome-wide search for genes conferring a predisposition to PPNAD, a second chromosomal locus located at 5q13 was identified $(62,63)$. This locus contains the gene encoding PDE8B. The PDE $8 B$ coding region was then sequenced in 22 patients with isolated micronodular adrenal disease and Cushing syndrome and a single base substitution
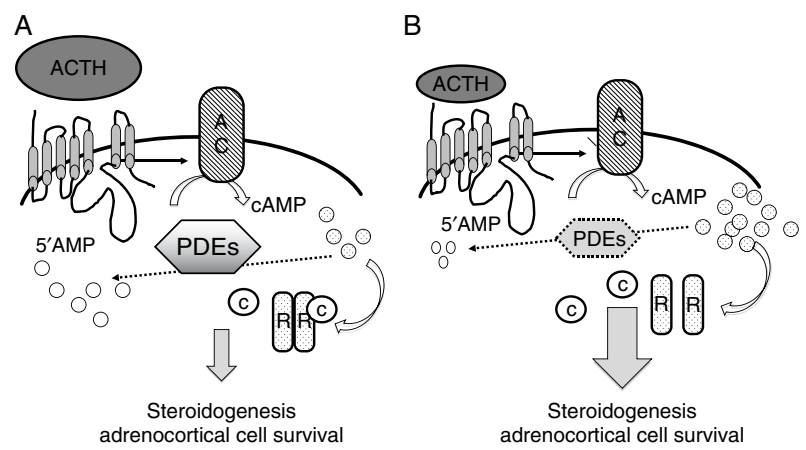

Figure 3 Phosphodiesterases in adrenal Cushing syndrome. (A) The left part of the figure shows the control of the cAMP pathway in the normal adrenal cortex. The pituitary hormone ACTH (adrenocorticotropin) stimulates its specific seven-transmembrane receptor, leading to activation of adenylyl cyclase (AC) and cAMP synthesis. CAMP activate the protein kinase $A$ made of two regulatory subunits $(R)$ and two catalytic subunits $(C)$. Activation of the phosphodiesterases (PDEs) stimulates degradation of CAMP to $5^{\prime}$-AMP leading to cAMP levels decrease. ACTH stimulates steroid synthesis and secretion and is required for adrenocortical cells survival. (B) The right part of the figure illustrates the dysregulation caused by PDE8B or PDE11A inactivating mutations. The reduced PDE activity leads to increased cAMP levels and PKA stimulation. This potentiates or mimics the effects of ACTH and takes part in the steroid oversecretion and/or adrenal nodular hyperplasia observed in animal models and/or human diseases. In adrenal Cushing syndrome, the negative feedback of cortisol on the hypothalamic and pituitary adrenal axis lead to reduced ACTH circulating levels. 
(c.914A $\rightarrow$ C, p.His305Pro) was found in one patient. This substitution was not found in any of the 1030 unrelated control subjects studied (62).

In vitro studies performed in HEK 293 cells significantly showed higher cAMP levels after transfection with the mutant $P D E 8 B$, indicating an impaired ability of the protein to degrade cAMP $(62,63)$.

\section{Thyroid}

PDESB As previously described, PDE $8 B$ genetic variants may be involved in regulation of TSH levels and could be responsible for the increased serum TSH occasionally observed in individuals with no evidence of thyroid autoimmunity or loss of function mutations in the thyroid hormone or TSHR genes (34).

PDE $8 B$ could also have a role in the regulation of thyroid function during pregnancy (64). Serum TSH, Free $\mathrm{T}_{4}$, and Free $\mathrm{T}_{3}$ were measured in 970 pregnant women at 28 weeks of gestation. The single nucleotide polymorphism rs4704397 genotype was available in 877 subjects. It was shown that TSH varied with genotype and was highest in patients with the AA genotype. These results suggested that a single nucleotide polymorphism in PDE $8 B$ leads to serum TSH concentration in the upper limit of the reference range and could even be associated with subclinical hypothyroidism during pregnancy.

PDE4 In autonomous thyroid adenomas, cAMP signaling can be constitutively activated by mutations affecting two elements, the TSHR and the Gs $\alpha$ protein. Although somatic mutations in the TSHR gene are a frequent finding in autonomous thyroid adenomas, somatic mutations of the Gs $\alpha$ gene are rare. It was also shown that some PDEs could have a role in the pathogenesis of these adenomas. A study demonstrated a PDE4 induction in the autonomous thyroid adenomas bearing a TSHR or Gs $\alpha$ mutation (65). In these tumors, a two to threefold increase in total PDE activity was observed. The authors demonstrated that this increase was due to the increase of PDE 4 activity, with a tenfold higher activity than measured in the surrounding normal tissue. These results indicate that the constitutive activation of the cAMP pathway in autonomous thyroid adenomas is associated with the upregulation of PDE4. This suggests that in these adenomas, the induction of specific PDE expression constitutes a mechanism opposing the chronic cAMP increase.

\section{Pituitary}

It is well established that somatotroph cells represent a cell type in which the activation of the cAMP-dependant pathway leads to cell proliferation and differentiation. As a consequence, alterations of the cAMP pathway appear to be molecular hallmarks of most GH-secreting adenomas $(9,66)$. As PDEs catalyze cAMP, some authors hypothesize the role of these enzymes in the pathogenesis of GH-secreting adenoma.

PDE4 It was initially shown that PDE activity was dramatically increased in human GH-secreting adenomas with activating Gs $\alpha$ mutations compared with wild-type Gs $\alpha$ adenomas and normal pituitary (37, 67). This high PDE activity was caused largely by PDE4. Indeed, a selective PDE4 inhibitor, rolipram, is nearly as effective as IBMX, a non-selective PDE inhibitor, in stimulating cAMP accumulation in intact cells and blocking the enzyme activity in membrane preparations.

The aryl hydrocarbon receptor-interacting protein (AIP) is a co-chaperon protein involved in the functional maturation of aryl hydrocarbon receptor. It has previously been shown that germ-line mutations in the gene encoding AIP cause pituitary adenomas predisposition (68). Close interactions were demonstrated between AIP and PDE4A5 (69). Indeed, AIP mutations disrupt protein interaction between AIP and PDE4A5 (70, 71). Another PDE, PDE2A, is also a known partner of AIP (72).

PDESB The induction of PDE isoforms by gsp mutations was not limited to $P D E 4$, but also involved $P D E 8 B$. Indeed, it was shown that expression of $P D E 8 B$ was absent in the normal pituitary but was detectable in almost all GH-secreting adenomas and higher in adenomas with activating mutations of the Gs $\alpha$ gene (37).

PDE11A Recently, one study screened 78 acromegalic patients and 110 controls for the presence of variants of the PDE11A gene (73). The frequency of PDE11A missense variants in acromegalic patients was found to be only slightly increased compared with controls. In addition, the presence of the wild-type allele resulting in the normal expression of the enzyme in the majority of tumor tissues together with the lack of significant clinical phenotype suggests that these variants might only marginally contribute to the development of GH-secreting adenomas.

\section{Gonads}

Testis PDE11A. The PDE11A gene coding region was sequenced in 95 patients with testicular germ cell tumors from 64 unrelated multiple-case kindreds (74). Non-synonymous substitutions of PDE11A have been detected with a frequency significantly higher in patients with familial and bilateral testicular germ cell tumors compared with controls. Moreover, functional studies showed that these mutations reduce PDE activity and increase cAMP levels. Thus, PDE11Ainactivating sequence variants may contribute to inherited testicular germ line tumor susceptibility. 
Ovary As it was shown that $P D E 8 A$ is a key regulator of LH signaling and testosterone production in Leydig cells, one study evaluated the human PDE8A gene as a polycystic ovary syndrome (PCOS) candidate gene (75). This was based on the hypothesis that reduced PDE 8 activity or expression would contribute to excessive ovarian androgen production. However, these authors showed that the more common of these PDE 8A variants were not associated with PCOS, excluding a significant role of PDE $8 A$ as PCOS candidate gene.

\section{Conclusion}

Significant progress has been made toward the elucidation of the role of PDE in endocrine physiology. This is not surprising, considering the important role of the cAMP signaling pathway in endocrine glands. However, as is often seen in the progress of cell biology, the mechanisms that inactivate a cellular function are studied later than the activating mechanisms. Over the last decade, several observations have shown a dysregulation of PDEs in endocrine diseases. As the development of specific drugs to target PDEs have been successful in non-endocrine diseases, and the development of new drugs is conceivable, this could lead to new therapeutic approaches in endocrine disorders. However, despite the recent progress summarized in this review, it is clear that the field needs to be investigated more deeply. There is no doubt that future studies of PDEs will reveal new aspects of the endocrine physiology and pathophysiology helping to progress toward new treatments.

\section{Declaration of interest}

The authors declare that there is no conflict of interest that could be perceived as prejudicing the impartiality of the research reported.

\section{Funding}

Our work is supported in part by the Agence Nationale de la Recherche (ANR08-GENOPAT-002; and ANR-10-Blan-1136). D Vezzosi is the recipient of a fellowship from the Institut National du Cancer (INCa).

\section{References}

1 Rosenberg D, Groussin L, Bertagna X \& Bertherat J. cAMP pathway alterations from the cell surface to the nucleus in adrenocortical tumors. Endocrine Research 200228 765-775. (doi:10.1081/ERC-120017071)

2 Parma J, Duprez L, Van Sande J, Cochaux P, Gervy C, Mockel J, Dumont J \& Vassart G. Somatic mutations in the thyrotropin receptor gene cause hyperfunctioning thyroid adenomas. Nature 1993365 649-651. (doi:10.1038/365649a0)

3 Liu G, Duranteau L, Carel JC, Monroe J, Doyle DA \& Shenker A. Leydig-cell tumors caused by an activating mutation of the gene encoding the luteinizing hormone receptor. New England Journal of Medicine 1999341 1731-1736. (doi:10.1056/ NEJM199912023412304)

4 Mancilla EE, De Luca F \& Baron J. Activating mutations of the $\mathrm{Ca}^{2+}$-sensing receptor. Molecular Genetics and Metabolism 1998 64 198-204. (doi:10.1006/mgme.1998.2716)

5 Lacroix A, N'Diaye N, Tremblay J \& Hamet P. Ectopic and abnormal hormone receptors in adrenal Cushing's syndrome. Endocrine Reviews 200122 75-110. (doi:10.1210/er.22.1.75)

6 Vezzosi D, Cartier D, Regnier C, Otal P, Bennet A, Parmentier F, Plantavid M, Lacroix A, Lefebvre $\mathrm{H}$ \& Caron P. Familial adrenocorticotropin-independent macronodular adrenal hyperplasia with aberrant serotonin and vasopressin adrenal receptors. European Journal of Endocrinology 2007156 21-31. (doi:10. 1530/eje.1.02324)

7 Groussin L, Perlemoine K, Contesse V, Lefebvre J, Tabarin A, Thieblot P, Schlienger JL, Luton JP, Bertagna X \& Bertherat J. The ectopic expression of the gastric inhibitory polypeptide receptor is frequent in adrenocorticotropin-independent bilateral macronodular adrenal hyperplasia, but rare in unilateral tumors. Journal of Clinical Endocrinology and Metabolism 200287 1980-1985. (doi:10.1210/jc.87.5.1980)

8 Weinstein LS, Shenker A, Gejman PV, Merino MJ, Friedman E \& Spiegel AM. Activating mutations of the stimulatory G protein in the McCune-Albright syndrome. New England Journal of Medicine 1991325 1688-1695. (doi:10.1056/NEJM199112 123252403)

9 Vallar L, Spada A \& Giannattasio G. Altered Gs and adenylate cyclase activity in human GH-secreting pituitary adenomas. Nature 1987330 566-568. (doi:10.1038/330566a0)

10 Kirschner LS, Sandrini F, Monbo J, Lin JP, Carney JA \& Stratakis CA. Genetic heterogeneity and spectrum of mutations of the PRKAR1A gene in patients with the Carney complex. Human Molecular Genetics 20009 3037-3046. (doi:10.1093/ $\mathrm{hmg} / 9.20 .3037)$

11 Veugelers M, Wilkes D, Burton K, McDermott DA, Song Y, Goldstein MM, La Perle K, Vaughan CJ, O'Hagan A, Bennett KR, Meyer BJ, Legius E, Karttunen M, Norio R, Kaariainen H, Lavyne M, Neau JP, Richter G, Kirali K, Farnsworth A, Stapleton K, Morelli P, Takanashi Y, Bamforth JS, Eitelberger F, Noszian I, Manfroi W, Powers J, Mochizuki Y, Imai T, Ko GT, Driscoll DA, Goldmuntz E, Edelberg JM, Collins A, Eccles D, Irvine AD, McKnight GS \& Basson CT. Comparative PRKAR1A genotype-phenotype analyses in humans with Carney complex and prkarla haploinsufficient mice. PNAS 2004101 14222-14227. (doi:10.1073/pnas.0405535101)

12 Groussin L, Kirschner LS, Vincent-Dejean C, Perlemoine K, Jullian E, Delemer B, Zacharieva S, Pignatelli D, Carney JA, Luton JP, Bertagna X, Stratakis CA \& Bertherat J. Molecular analysis of the cyclic AMP-dependent protein kinase A (PKA) regulatory subunit 1A (PRKAR1A) gene in patients with Carney complex and primary pigmented nodular adrenocortical disease (PPNAD) reveals novel mutations and clues for pathophysiology: augmented PKA signaling is associated with adrenal tumorigenesis in PPNAD. American Journal of Human Genetics 200271 1433-1442. (doi:10.1086/344579)

13 Hansen G, Jin S, Umetsu DT \& Conti M. Absence of muscarinic cholinergic airway responses in mice deficient in the cyclic nucleotide phosphodiesterase PDE4D. PNAS $2000 \quad \mathbf{9 7}$ 6751-6756. (doi:10.1073/pnas.97.12.6751)

14 Zhang HT, Huang Y, Jin SL, Frith SA, Suvarna N, Conti M \& O'Donnell JM. Antidepressant-like profile and reduced sensitivity to rolipram in mice deficient in the PDE4D phosphodiesterase enzyme. Neuropsychopharmacology 200227 587-595. (doi:10. 1016/S0893-133X(02)00344-5)

15 Millar JK, Pickard BS, Mackie S, James R, Christie S, Buchanan SR, Malloy MP, Chubb JE, Huston E, Baillie GS, Thomson PA, Hill EV, Brandon NJ, Rain JC, Camargo LM, Whiting PJ, Houslay MD, Blackwood DH, Muir WJ \& Porteous DJ. 
DISC1 and PDE4B are interacting genetic factors in schizophrenia that regulate cAMP signaling. Science $2005 \mathbf{3 1 0}$ 1187-1191. (doi:10.1126/science.1112915)

16 Gretarsdottir S, Thorleifsson G, Reynisdottir ST, Manolescu A, Jonsdottir S, Jonsdottir T, Gudmundsdottir T, Bjarnadottir SM, Einarsson OB, Gudjonsdottir HM, Hawkins M, Gudmundsson G, Gudmundsdottir $\mathrm{H}$, Andrason $\mathrm{H}$, Gudmundsdottir AS, Sigurdardottir M, Chou TT, Nahmias J, Goss S, Sveinbjornsdottir S, Valdimarsson EM, Jakobsson F, Agnarsson U, Gudnason V, Thorgeirsson G, Fingerle J, Gurney M, Gudbjartsson D, Frigge ML, Kong A, Stefansson K \& Gulcher JR. The gene encoding phosphodiesterase 4D confers risk of ischemic stroke. Nature Genetics 200335 131-138. (doi:10.1038/ng1245)

17 McVary KT. Clinical practice. Erectile dysfunction. New England Journal of Medicine 2007357 2472-2481. (doi:10.1056/ NEJMcp067261)

18 Kumar P, Francis GS \& Tang WH. Phosphodiesterase 5 inhibition in heart failure: mechanisms and clinical implications. Nature Reviews. Cardiology 20096 349-355. (doi:10.1038/nrcardio. 2009.32)

19 De LaVega AJ \& Derk CT. Phosphodiesterase-5 inhibitors for the treatment of Raynaud's: a novel indication. Expert Opinion on Investigational Drugs $2009 \mathbf{1 8}$ 23-29. (doi:10.1517/ 13543780802525100)

20 Archer SL \& Michelakis ED. Phosphodiesterase type 5 inhibitors for pulmonary arterial hypertension. New England Journal of Medicine 2009361 1864-1871. (doi:10.1056/NEJMct09 04473)

21 Lipworth BJ. Phosphodiesterase-4 inhibitors for asthma and chronic obstructive pulmonary disease. Lancet $2005 \mathbf{3 6 5}$ 167-175. (doi:10.1016/S0140-6736(05)17708-3)

22 Hertz AL, Bender AT, Smith KC, Gilchrist M, Amieux PS, Aderem A \& Beavo JA. Elevated cyclic AMP and PDE4 inhibition induce chemokine expression in human monocyte-derived macrophages. PNAS 2009106 21978-21983. (doi:10.1073/ pnas.0911684106)

23 Zaccolo M. Phosphodiesterases and compartmentalized cAMP signalling in the heart. European Journal of Cell Biology $2006 \mathbf{8 5}$ 693-697. (doi:10.1016/j.ejcb.2006.01.002)

24 Horvath A, Boikos S, Giatzakis C, Robinson-White A, Groussin L, Griffin KJ, Stein E, Levine E, Delimpasi G, Hsiao HP, Keil M, Heyerdahl S, Matyakhina L, Libe R, Fratticci A, Kirschner LS, Cramer K, Gaillard RC, Bertagna X, Carney JA, Bertherat J, Bossis I \& Stratakis CA. A genome-wide scan identifies mutations in the gene encoding phosphodiesterase 11A4 (PDE11A) in individuals with adrenocortical hyperplasia. Nature Genetics 200638 794-800. (doi:10.1038/ng1809)

25 Lakics V, Karran EH \& Boess FG. Quantitative comparison of phosphodiesterase mRNA distribution in human brain and peripheral tissues. Neuropharmacology $2010 \quad 59$ 367-374. (doi:10.1016/j.neuropharm.2010.05.004)

26 Bingham J, Sudarsanam S \& Srinivasan S. Profiling human phosphodiesterase genes and splice isoforms. Biochemical and Biophysical Research Communications 2006350 25-32. (doi:10. 1016/j.bbrc.2006.08.180)

27 Sonnenburg WK, Mullaney PJ \& Beavo JA. Molecular cloning of a cyclic GMP-stimulated cyclic nucleotide phosphodiesterase cDNA. Identification and distribution of isozyme variants. Journal of Biological Chemistry 1991266 17655-17661.

28 Tsai LC, Shimizu-Albergine M \& Beavo JA. The high affinity cAMP-specific phosphodiesterase 8B (PDE8B) controls steroidogenesis in the mouse adrenal gland. Molecular Pharmacology 201179 639-648. (doi:10.1124/mol.110.069104)

29 Cote M, Payet MD, Rousseau E, Guillon G \& Gallo-Payet N. Comparative involvement of cyclic nucleotide phosphodiesterases and adenylyl cyclase on adrenocorticotropin-induced increase of cyclic adenosine monophosphate in rat and human glomerulosa cells. Endocrinology 1999140 3594-3601. (doi:10.1210/en. 140.8.3594)
30 Wayman C, Phillips S, Lunny C, Webb T, Fawcett L, Baxendale R \& Burgess G. Phosphodiesterase 11 (PDE11) regulation of spermatozoa physiology. International Journal of Impotence Research 200517 216-223. (doi:10.1038/sj.ijir.3901307)

31 Di Luigi L, Baldari C, Sgro P, Emerenziani GP, Gallotta MC, Bianchini S, Romanelli F, Pigozzi F, Lenzi A \& Guidetti L. The type 5 phosphodiesterase inhibitor tadalafil influences salivary cortisol, testosterone, and dehydroepiandrosterone sulphate responses to maximal exercise in healthy men. Journal of Clinical Endocrinology and Metabolism 200893 3510-3514. (doi:10. 1210/jc.2008-0847)

32 Hansen PS, Brix TH, Sorensen TI, Kyvik KO \& Hegedus L. Major genetic influence on the regulation of the pituitary-thyroid axis: a study of healthy Danish twins. Journal of Clinical Endocrinology and Metabolism 200489 1181-1187. (doi:10.1210/jc.2003031641)

33 Panicker V, Wilson SG, Spector TD, Brown SJ, Falchi M, Richards JB, Surdulescu GL, Lim EM, Fletcher SJ \& Walsh JP. Heritability of serum TSH, free $\mathrm{T}_{4}$ and free $\mathrm{T}_{3}$ concentrations: a study of a large UK twin cohort. Clinical Endocrinology $2008 \mathbf{6 8}$ 652-659. (doi:10.1111/j.1365-2265.2007.03079.x)

34 Arnaud-Lopez L, Usala G, Ceresini G, Mitchell BD, Pilia MG, Piras MG, Sestu N, Maschio A, Busonero F, Albai G, Dei M, Lai S, Mulas A, Crisponi L, Tanaka T, Bandinelli S, Guralnik JM, Loi A, Balaci L, Sole G, Prinzis A, Mariotti S, Shuldiner AR, Cao A, Schlessinger D, Uda M, Abecasis GR, Nagaraja R, Sanna S \& Naitza S. Phosphodiesterase $8 \mathrm{~B}$ gene variants are associated with serum TSH levels and thyroid function. American Journal of Human Genetics 200882 1270-1280. (doi:10.1016/j.ajhg. 2008.04.019)

35 Loughney K, Taylor J \& Florio VA. 3',5'-cyclic nucleotide phosphodiesterase 11A: localization in human tissues. International Journal of Impotence Research 200517 320-325. (doi:10. 1038/sj.ijir.3901317)

36 Stephenson DT, Coskran TM, Wilhelms MB, Adamowicz WO, O'Donnell MM, Muravnick KB, Menniti FS, Kleiman RJ \& Morton D. Immunohistochemical localization of phosphodiesterase $2 \mathrm{~A}$ in multiple mammalian species. Journal of Histochemistry and Cytochemistry 200957 933-949. (doi:10.1369/jhc.2009. 953471)

37 Persani L, Borgato S, Lania A, Filopanti M, Mantovani G, Conti M \& Spada A. Relevant cAMP-specific phosphodiesterase isoforms in human pituitary: effect of Gs(alpha) mutations. Journal of Clinical Endocrinology and Metabolism 200186 3795-3800. (doi:10.1210/jc.86.8.3795)

38 Ang KL \& Antoni FA. Functional plasticity of cyclic AMP hydrolysis in rat adenohypophysial corticotroph cells. Cell Signalling 200214 445-452. (doi:10.1016/S0898-6568(01) 00267-4)

39 Azhar S \& Menon KM. Cyclic nucleotide phosphodiesterases from rat anterior pituitary. Characterization of multiple forms and regulation by protein activator and $\mathrm{Ca}^{+}$. European Journal of Biochemistry 197773 73-82. (doi:10.1111/j.1432-1033.1977. tb11292.x)

40 Nagasaka A, Ohkubo S \& Hidaka H. 3':5'-cyclic-nucleotide phosphodiesterase in the bovine pituitary gland. Biochimica et Biophysica Acta $1983 \mathbf{7 5 5} 481-487$.

41 Gonzalez-Iglesias AE, Jiang Y, Tomic M, Kretschmannova K, Andric SA, Zemkova H \& Stojilkovic SS. Dependence of electrical activity and calcium influx-controlled prolactin release on adenylyl cyclase signaling pathway in pituitary lactotrophs. Molecular Endocrinology 200620 2231-2246. (doi:10.1210/ me.2005-0363)

42 Kumari M, Cover PO, Poyser RH \& Buckingham JC. Stimulation of the hypothalamo-pituitary-adrenal axis in the rat by three selective type-4 phosphodiesterase inhibitors: in vitro and in vivo studies. British Journal of Pharmacology 1997121 459-468. (doi:10.1038/sj.bjp.0701158)

43 Hadley AJ, Kumari M, Cover PO, Osborne J, Poyser R, Flack JD \& Buckingham JC. Stimulation of the hypothalamo-pituitary- 
adrenal axis in the rat by the type 4 phosphodiesterase (PDE-4) inhibitor, denbufylline. British Journal of Pharmacology 1996119 463-470.

44 D'Andrea MR, Qiu Y, Haynes-Johnson D, Bhattacharjee S, Kraft P \& Lundeen S. Expression of PDE11A in normal and malignant human tissues. Journal of Histochemistry and Cytochemistry 2005 53 895-903. (doi:10.1369/jhc.5A6625.2005)

45 Wang P, Wu P, Egan RW \& Billah MM. Human phosphodiesterase 8A splice variants: cloning, gene organization, and tissue distribution. Gene $20012 \mathbf{2 8 0}$ 183-194. (doi:10.1016/S03781119(01)00783-1)

46 Hellstrom WJ, Overstreet JW, Yu A, Saikali K, Shen W, Beasley CM Jr \& Watkins VS. Tadalafil has no detrimental effect on human spermatogenesis or reproductive hormones. Journal of Urology 2003170 887-891. (doi:10.1097/01.ju.0000081053. 97792.da)

47 Pomara G, Morelli G, Canale D, Turchi P, Caglieresi C, Moschini C, Liguori G, Selli C, Macchia E, Martino E \& Francesca F. Alterations in sperm motility after acute oral administration of sildenafil or tadalafil in young, infertile men. Fertility and Sterility 200788 860-865. (doi:10.1016/j.fertnstert.2006.12.019)

48 Bischoff E. Potency, selectivity, and consequences of nonselectivity of PDE inhibition. International Journal of Impotence Research 200416 (Suppl 1) S11-S14. (doi:10.1038/sj.ijir.3901208)

49 Saez JM. Leydig cells: endocrine, paracrine, and autocrine regulation. Endocrine Reviews 199415 574-626. (doi:10. 1210/edrv-15-5-574)

50 Vasta V, Shimizu-Albergine M \& Beavo JA. Modulation of Leydig cell function by cyclic nucleotide phosphodiesterase 8A. PNAS 2006103 19925-19930. (doi:10.1073/pnas.0609483103)

51 Sasseville M, Albuz FK, Cote N, Guillemette C, Gilchrist RB \& Richard FJ. Characterization of novel phosphodiesterases in the bovine ovarian follicle. Biology of Reproduction $2009 \mathbf{8 1}$ 415-425. (doi:10.1095/biolreprod.108.074450)

52 Nogueira D, Albano C, Adriaenssens T, Cortvrindt R, Bourgain C, Devroey P \& Smitz J. Human oocytes reversibly arrested in prophase I by phosphodiesterase type 3 inhibitor in vitro. Biology of Reproduction 200369 1042-1052. (doi:10.1095/biolreprod. 103.015982)

53 Conti M, Andersen CB, Richard F, Mehats C, Chun SY, Horner K, Jin C \& Tsafriri A. Role of cyclic nucleotide signaling in oocyte maturation. Molecular and Cellular Endocrinology $2002 \quad 187$ 153-159. (doi:10.1016/S0303-7207(01)00686-4)

54 Masciarelli S, Horner K, Liu C, Park SH, Hinckley M, Hockman S, Nedachi T, Jin C, Conti M \& Manganiello V. Cyclic nucleotide phosphodiesterase 3A-deficient mice as a model of female infertility. Journal of Clinical Investigation 2004114 196-205. (doi:10.1172/JCI21804)

55 Tsafriri A, Chun SY, Zhang R, Hsueh AJ \& Conti M. Oocyte maturation involves compartmentalization and opposing changes of cAMP levels in follicular somatic and germ cells: studies using selective phosphodiesterase inhibitors. Developmental Biology 1996178 393-402. (doi:10.1006/dbio.1996. 0226)

56 McKenna SD, Pietropaolo M, Tos EG, Clark A, Fischer D, Kagan D, Bao B, Chedrese PJ \& Palmer S. Pharmacological inhibition of phosphodiesterase 4 triggers ovulation in follicle-stimulating hormone-primed rats. Endocrinology $2005146 \quad 208-214$. (doi:10.1210/en.2004-0562)

57 Jin SL, Richard FJ, Kuo WP, D’Ercole AJ \& Conti C. Impaired growth and fertility of cAMP-specific phosphodiesterase PDE4Ddeficient mice. PNAS 199996 11998-12003. (doi:10.1073/ pnas.96.21.11998)

58 Kirschner LS, Carney JA, Pack SD, Taymans SE, Giatzakis C, Cho YS, Cho-Chung YS \& Stratakis CA. Mutations of the gene encoding the protein kinase A type I-alpha regulatory subunit in patients with the Carney complex. Nature Genetics 200026 89-92. (doi:10.1038/79238)

59 Horvath A, Giatzakis C, Robinson-White A, Boikos S, Levine E, Griffin K, Stein E, Kamvissi V, Soni P, Bossis I, de Herder W, Carney JA, Bertherat J, Gregersen PK, Remmers EF \&
Stratakis CA. Adrenal hyperplasia and adenomas are associated with inhibition of phosphodiesterase 11A in carriers of PDE11A sequence variants that are frequent in the population. Cancer Research $2006 \mathbf{6 6} 11571-11575$. (doi:10.1158/0008-5472. CAN-06-2914)

60 Libe R, Fratticci A, Coste J, Tissier F, Horvath A, Ragazzon B, Rene-Corail F, Groussin L, Bertagna X, Raffin-Sanson ML, Stratakis CA \& Bertherat J. Phosphodiesterase 11A (PDE11A) and genetic predisposition to adrenocortical tumors. Clinical Cancer Research 200814 4016-4024. (doi:10.1158/10780432.CCR-08-0106)

61 Libe R, Horvath A, Vezzosi D, Fratticci A, Coste J, Perlemoine K, Ragazzon B, Guillaud-Bataille M, Groussin L, Clauser E, RaffinSanson ML, Siegel J, Moran J, Drori-Herishanu L, Faucz FR, Lodish M, Nesterova M, Bertagna X, Bertherat J \& Stratakis CA. Frequent phosphodiesterase 11A gene (PDE11A) defects in patients with Carney complex (CNC) caused by PRKAR1A mutations: PDE11A may contribute to adrenal and testicular tumors in $\mathrm{CNC}$ as a modifier of the phenotype. Journal of Clinical Endocrinology and Metabolism 201196 E208-E214. (doi:10. 1210/jc.2010-1704)

62 Horvath A, Giatzakis C, Tsang K, Greene E, Osorio P, Boikos S, Libe R, Patronas Y, Robinson-White A, Remmers E, Bertherat J, Nesterova M \& Stratakis CA. A cAMP-specific phosphodiesterase (PDE8B) that is mutated in adrenal hyperplasia is expressed widely in human and mouse tissues: a novel PDE8B isoform in human adrenal cortex. European Journal of Human Genetics 2008 16 1245-1253. (doi:10.1038/ejhg.2008.85)

63 Horvath A, Mericq V \& Stratakis CA. Mutation in PDE8B, a cyclic AMP-specific phosphodiesterase in adrenal hyperplasia. New England Journal of Medicine 2008358 750-752. (doi:10.1056/ NEJMc0706182)

64 Shields BM, Freathy RM, Knight BA, Hill A, Weedon MN, Frayling TM, Hattersley AT \& Vaidya B. Phosphodiesterase 8B gene polymorphism is associated with subclinical hypothyroidism in pregnancy. Journal of Clinical Endocrinology and Metabolism 200994 4608-4612. (doi:10.1210/jc.2009-1298)

65 Persani L, Lania A, Alberti L, Romoli R, Mantovani G, Filetti S, Spada A \& Conti M. Induction of specific phosphodiesterase isoforms by constitutive activation of the cAMP pathway in autonomous thyroid adenomas. Journal of Clinical Endocrinology and Metabolism $2000 \mathbf{8 5}$ 2872-2878. (doi:10.1210/jc.85.8. 2872)

66 Lania AG, Mantovani G, Ferrero S, Pellegrini C, Bondioni S, Peverelli E, Braidotti P, Locatelli M, Zavanone ML, Ferrante E, Bosari S, Beck-Peccoz P \& Spada A. Proliferation of transformed somatotroph cells related to low or absent expression of protein kinase a regulatory subunit 1 A protein. Cancer Research 200464 9193-9198. (doi:10.1158/0008-5472.CAN-04-1847)

67 Lania A, Persani L, Ballare E, Mantovani S, Losa M \& Spada A. Constitutively active Gs alpha is associated with an increased phosphodiesterase activity in human growth hormone-secreting adenomas. Journal of Clinical Endocrinology and Metabolism 1998 83 1624-1628. (doi:10.1210/jc.83.5.1624)

68 Vierimaa O, Georgitsi M, Lehtonen R, Vahteristo P, Kokko A, Raitila A, Tuppurainen K, Ebeling TM, Salmela PI, Paschke R, Gundogdu S, De Menis E, Makinen MJ, Launonen V, Karhu A \& Aaltonen LA. Pituitary adenoma predisposition caused by germline mutations in the AIP gene. Science $2006 \mathbf{3 1 2}$ 1228-1230. (doi:10.1126/science.1126100)

69 Leontiou CA, Gueorguiev M, van der Spuy J, Quinton R, Lolli F, Hassan S, Chahal HS, Igreja SC, Jordan S, Rowe J, Stolbrink M, Christian HC, Wray J, Bishop-Bailey D, Berney DM, Wass JA, Popovic V, Ribeiro-Oliveira A Jr, Gadelha MR, Monson JP, Akker SA, Davis JR, Clayton RN, Yoshimoto K, Iwata T, Matsuno A, Eguchi K, Musat M, Flanagan D, Peters G, Bolger GB, Chapple JP, Frohman LA, Grossman AB \& Korbonits M. The role of the aryl hydrocarbon receptorinteracting protein gene in familial and sporadic pituitary adenomas. Journal of Clinical Endocrinology and Metabolism 200893 2390-2401. (doi:10.1210/jc.2007-2611) 
70 Bolger GB, Peden AH, Steele MR, MacKenzie C, McEwan DG, Wallace DA, Huston E, Baillie GS \& Houslay MD. Attenuation of the activity of the cAMP-specific phosphodiesterase PDE4A5 by interaction with the immunophilin XAP2. Journal of Biological Chemistry 2003278 33351-33363. (doi:10.1074/jbc. M303269200)

71 Igreja S, Chahal HS, King P, Bolger GB, Srirangalingam U, Guasti L, Chapple JP, Trivellin G, Gueorguiev M, Guegan K, Stals K, Khoo B, Kumar AV, Ellard S, Grossman AB \& Korbonits M. Characterization of aryl hydrocarbon receptor interacting protein (AIP) mutations in familial isolated pituitary adenoma families. Human Mutation 201031 950-960. (doi:10. 1002/humu.21292)

72 de Oliveira SK, Hoffmeister M, Gambaryan S, Muller-Esterl W, Guimaraes JA \& Smolenski AP. Phosphodiesterase 2A forms a complex with the co-chaperone XAP2 and regulates nuclear translocation of the aryl hydrocarbon receptor. Journal of Biological Chemistry 2007282 13656-13663. (doi:10.1074/ jbc.M610942200)

73 Peverelli E, Ermetici F, Filopanti M, Elli FM, Ronchi CL, Mantovani G, Ferrero S, Bosari S, Beck-Peccoz P, Lania A \& Spada A. Analysis of genetic variants of phosphodiesterase 11A in acromegalic patients. European Journal of Endocrinology 2009 161 687-694. (doi:10.1530/EJE-09-0677)

74 Horvath A, Korde L, Greene MH, Libe R, Osorio P, Faucz FR, Raffin-Sanson ML, Tsang KM, Drori-Herishanu L, Patronas Y, Remmers EF, Nikita ME, Moran J, Greene J, Nesterova M, Merino M, Bertherat J \& Stratakis CA. Functional phosphodiesterase $11 \mathrm{~A}$ mutations may modify the risk of familial and bilateral testicular germ cell tumors. Cancer Research 200969 5301-5306. (doi:10.1158/0008-5472.CAN-09-0884)

75 Chen C, Wickenheisser J, Ewens KG, Ankener W, Legro RS, Dunaif A, McAllister JM, Spielman RS \& Strauss J III. PDE8A genetic variation, polycystic ovary syndrome and androgen levels in women. Molecular Human Reproduction 200915 459-469. (doi:10.1093/molehr/gap035)

76 Omori K \& Kotera J. Overview of PDEs and their regulation. Circulation Research 2007100 309-327. (doi:10.1161/01.RES. 0000256354.95791.f1)

77 Conti M \& Beavo J. Biochemistry and physiology of cyclic nucleotide phosphodiesterases: essential components in cyclic nucleotide signaling. Annual Review of Biochemistry $2007 \mathbf{7 6}$ 481-511. (doi:10.1146/annurev.biochem.76.060305.150444)

78 Michibata H, Yanaka N, Kanoh Y, Okumura K \& Omori K. Human $\mathrm{Ca}^{2+}$ /calmodulin-dependent phosphodiesterase PDE1A: novel splice variants, their specific expression, genomic organization, and chromosomal localization. Biochimica et Biophysica Acta $2001 \quad 1517$ 278-287. (doi:10.1016/S0167-4781(00) 00293-1)

79 Bender AT \& Beavo JA. Cyclic nucleotide phosphodiesterases: molecular regulation to clinical use. Pharmacological Reviews 200658 488-520. (doi:10.1124/pr.58.3.5)

80 Jeon KI, Jono H, Miller CL, Cai Y, Lim S, Liu X, Gao P, Abe J, Li JD \& Yan C. $\mathrm{Ca}^{2+} /$ calmodulin-stimulated PDE1 regulates the beta-catenin/TCF signaling through PP2A B56 gamma subunit in proliferating vascular smooth muscle cells. FEBS Journal 2010277 5026-5039. (doi:10.1111/j.1742-4658. 2010.07908.x)

81 Sadhu K, Hensley K, Florio VA \& Wolda SL. Differential expression of the cyclic GMP-stimulated phosphodiesterase PDE2A in human venous and capillary endothelial cells. Journal of Histochemistry and Cytochemistry 199947 895-906. (doi:10. 1177/002215549904700707)

82 Mongillo M, Tocchetti CG, Terrin A, Lissandron V, Cheung YF, Dostmann WR, Pozzan T, Kass DA, Paolocci N, Houslay MD \& Zaccolo M. Compartmentalized phosphodiesterase-2 activity blunts beta-adrenergic cardiac inotropy via an NO/cGMPdependent pathway. Circulation Research 200698 226-234. (doi:10.1161/01.RES.0000200178.34179.93)
83 MacFarland RT, Zelus BD \& Beavo JA. High concentrations of a cGMP-stimulated phosphodiesterase mediate ANP-induced decreases in cAMP and steroidogenesis in adrenal glomerulosa cells. Journal of Biological Chemistry 1991266 136-142.

84 Pyne NJ \& Furman BL. Cyclic nucleotide phosphodiesterases in pancreatic islets. Diabetologia 200346 1179-1189. (doi:10. 1007/s00125-003-1176-7)

85 Degerman E \& Manganiello VC. Phosphodiesterase 3B; an important regulator of energy homeostasis. In Cyclic Phosphodiesterases in Health and Disease, pp 79-99. Eds JA Beavo, MD Houslay \& SH Frances, Broca Raton, FL, USA: CRC Press, 2007.

86 Waddleton D, Wu W, Feng Y, Thompson C, Wu M, Zhou YP, Howard A, Thornberry N, Li J \& Mancini JA. Phosphodiesterase 3 and 4 comprise the major cAMP metabolizing enzymes responsible for insulin secretion in INS-1 $(832 / 13)$ cells and rat islets. Biochemical Pharmacology 200876 884-893. (doi:10. 1016/j.bcp.2008.07.025)

87 Shakur Y, Holst LS, Landstrom TR, Movsesian M, Degerman E \& Manganiello V. Regulation and function of the cyclic nucleotide phosphodiesterase (PDE3) gene family. Progress in Nucleic Acid Research and Molecular Biology 200166 241-277. (doi:10.1016/ S0079-6603(00)66031-2)

88 Reinhardt RR, Chin E, Zhou J, Taira M, Murata T, Manganiello VC \& Bondy CA. Distinctive anatomical patterns of gene expression for cGMP-inhibited cyclic nucleotide phosphodiesterases. Journal of Clinical Investigation 199595 1528-1538. (doi:10. 1172/JCI117825)

89 Degerman E, Belfrage P \& Manganiello VC. Structure, localization, and regulation of cGMP-inhibited phosphodiesterase (PDE3). Journal of Biological Chemistry 1997272 6823-6826. (doi:10.1074/jbc.272.11.6823)

90 Zhang R, Maratos-Flier E \& Flier JS. Reduced adiposity and highfat diet-induced adipose inflammation in mice deficient for phosphodiesterase 4B. Endocrinology 2009150 3076-3082. (doi:10.1210/en.2009-0108)

91 Bolger G, Michaeli T, Martins T, St John T, Steiner B, Rodgers L, Riggs M, Wigler M \& Ferguson K. A family of human phosphodiesterases homologous to the dunce learning and memory gene product of Drosophila melanogaster are potential targets for antidepressant drugs. Molecular and Cellular Biology $1993136558-6571$.

92 Houslay MD \& Adams DR. PDE4 cAMP phosphodiesterases: modular enzymes that orchestrate signalling cross-talk, desensitization and compartmentalization. Biochemical Journal 2003 370 1-18. (doi:10.1042/BJ20021698)

93 Wang P, Wu P, Myers JG, Stamford A, Egan RW \& Billah MM. Characterization of human, dog and rabbit corpus cavernosum type 5 phosphodiesterases. Life Sciences 200168 1977-1987. (doi:10.1016/S0024-3205(01)00989-4)

94 Qiu Y, Kraft P, Lombardi E \& Clancy J. Rabbit corpus cavernosum smooth muscle shows a different phosphodiesterase profile than human corpus cavernosum. Journal of Urology $2000164882-$ 886. (doi:10.1016/S0022-5347(05)67331-4)

95 Ito M, Nishikawa M, Fujioka M, Miyahara M, Isaka N, Shiku H \& Nakano T. Characterization of the isoenzymes of cyclic nucleotide phosphodiesterase in human platelets and the effects of E4021. Cellular Signalling 19968 575-581. (doi:10.1016/S08986568(96)00112-X)

96 Kass DA, Champion HC \& Beavo JA. Phosphodiesterase type 5: expanding roles in cardiovascular regulation. Circulation Research 2007101 1084-1095. (doi:10.1161/CIRCRESAHA.107.162 511)

97 Ionita MA \& Pittler SJ. Focus on molecules: rod cGMP phosphodiesterase type 6. Experimental Eye Research $2007 \mathbf{8 4}$ 1-2. (doi:10.1016/j.exer.2005.12.012)

98 Giembycz MA \& Smith SJ. Phosphodiesterase 7A: a new therapeutic target for alleviating chronic inflammation? Current Pharmaceutical Design 200612 3207-3220. (doi:10.2174/ 138161206778194123) 
99 Rentero C, Monfort A \& Puigdomenech P. Identification and distribution of different mRNA variants produced by differential splicing in the human phosphodiesterase 9A gene. Biochemical and Biophysical Research Communications $2003301686-692$. (doi:10.1016/S0006-291X(03)00021-4)

100 Wang P, Wu P, Egan RW \& Billah MM. Identification and characterization of a new human type 9 cGMP-specific phosphodiesterase splice variant (PDE9A5). Differential tissue distribution and subcellular localization of PDE9A variants. Gene 2003314 15-27. (doi:10.1016/S0378-1119(03)00733-9)

101 Kumar KG, DiCarlo LM, Volaufova J, Zuberi AR \& Richards BK. Increased physical activity cosegregates with higher intake of carbohydrate and total calories in a subcongenic mouse strain. Mammalian Genome 201021 52-63. (doi:10.1007/s00335009-9243-0)

102 Kleiman RJ, Kimmel LH, Bove SE, Lanz TA, Harms JF Romegialli A, Miller KS, Willis A, des Etages S, Kuhn M \& Schmidt CJ. Chronic suppression of phosphodiesterase 10A alters striatal expression of genes responsible for neurotransmitter synthesis, neurotransmission, and signaling pathways implicated in Huntington's disease. Journal of Pharmacology and Experimental Therapeutics 2011336 64-76. (doi:10.1124/jpet. $110.173294)$

103 Yuasa K, Kotera J, Fujishige K, Michibata H, Sasaki T \& Omori K. Isolation and characterization of two novel phosphodiesterase PDE11A variants showing unique structure and tissue-specific expression. Journal of Biological Chemistry 2000275 3146931479. (doi:10.1074/jbc.M003041200)

104 Fawcett L, Baxendale R, Stacey P, McGrouther C, Harrow I, Soderling S, Hetman J, Beavo JA \& Phillips SC. Molecular cloning and characterization of a distinct human phosphodiesterase gene family: PDE11A. PNAS 200097 3702-3707. (doi:10.1073/ pnas.050585197)

Received 20 April 2011

Accepted 16 May 2011 